\title{
The Case of the Real Taxpayer: A Reply to Professor Bittker
}

\author{
Kenneth Culp Davis †
}

\section{Supreme Court of the United States (Nov. 23, 1993)}

PER GURIAM. This case, erroneously entitled below "The Case of the Fictitious Taxpayer," raises two questions: (1) Is one who pays a tax a payer of a tax? (2) Is a payer of a tax a taxpayer? Our answer to each question is yes, and we reject the district court's unnecessary qualifications.

On these two questions, this Court, stimulated by the sparkling wit of Professor Bittker, has sunk into bemuddled fuddles and befuddled muddles, described in the district court's opinion. In response to ridicule from the segments of the society that retain a sense of smell for intellectual quicksand, we now cut ourselves loose from the ridiculous refinements of the district court's opinion, and we adopt the cleancut proposition that one who pays a tax is a taxpayer, whether or not the winds of chance have blown the taxpayer to an airport, whether or not the taxpayer is a citizen, and whether or not the taxpayer is reimbursed. Furthermore, we adhere to our holding, discussed in the district court's opinion, that one who bears any part of the burden of a tax is a taxpayer; that holding renders irrelevant most of the district court's opinion, as the district court should have recognized, for anyone who spends money in the United States is likely to bear some of the burden of one or more excise taxes.

The district court's opinion is seriously mistaken in assuming that standing of a taxpayer is equivalent to the "public action" advanced by Professor Jaffe. We held in Flast that a taxpayer may have standing to challenge federal disbursements, but we did not hold that citizenship alone is enough for standing. To show that taxpayers and citizens are not equivalents, we shall now review our holdings in the three Chiang cases.

A Chinese woman had three sons. The first, Chiang Kai Wun, was born in China. The second, Chiang Kai Tu, was born in the United

† John P. Wilson Professor of Law, The University of Chicago. 
States while his mother was a student at Wellesley College. The third, Chiang Kai Tre, was born in China after his mother returned.

Chiang Kai Wun started selling hot cakes in New York City when he was fourteen; they sold like hot cakes, and he branched out into gold cakes, uranium cakes, nuclear cakes, and mutual cakes, with enterprises a hundred times the size of General Motors. When New York City spent federal funds for parochial schools, Chiang Kai Wun asked his lawyers to get a declaratory judgment that the expenditures violated the establishment clause. This Court followed Professor Jaffe, who had written that "The citizen, as the prime political unit of the democracy, should be the plaintiff." Chiang Kai Wun was not a citizen. That he had a few millions at stáke as the biggest taxpayer in the world did not matter, for Jaffe had written that "the likely size of the tax bill, and what is more to the point, the impact of the allegedly illegal expenditure on the plaintiff's own tax liability a're irrelevant."2

The lawyers then sued on behalf of Chiang Kai Tu, who had spent his entire life in an institution for the mentally retarded in the interior of China. The government lawyers produced conclusive evidence that the institution had a rigid policy of buying only local products and that Chiang Kai Tu had never heard of New York City, of schools, or of taxes. But the Court, following Jaffe, held that the test of standing was citizenship, that the plaintiff was a citizen, and that, quoting Jaffe, "the impact" on the plaintiff was "irrelevant." If the impact was irrelevant, the lack of impact was irrelevant, the Court reasoned.

Meantime, Chiang Kai Tre, the bright brother, simultaneously headed the espionáge systems of nine countries, including the United States and the Soviet Union, but was exposed in 1992, during the closing days of the Vietnam war, when liquid computer tape leaked out of his flask. He sought judicial review of the order to execute him. The government lawyers conceded that he had been denied due process in 67 ways, but they asserted lack of standing. Although the Jaffe view

1 L. Jafke, Júdicial Control of administrative Áction 486 (1965). Like Professor Bittker, this Court overlooked the further Jaffe position that "Perhaps there is a good case for retaining the taxpayer action as a supplement where there is in fact a waste of funds." In this aspect, Professor Jaffe does not reject the taxpayer action, and in this aspect he and Professor Bittker are evidently taking opposite positions, to the extent that Bittker is rejecting the taxpayer action. Not only do Bittker and Jaffe differ in that Jaffe properly recognizes the need for allowing taxpayers' actions even if citizens have standing, but they also differ in that Jaffe courageously takes an affirmative position about standing while Bittker is wholly negative. We think that if Bittker would try to solve the problem of standing, instead of limiting himself to ridiculing those who do try, including this Court, he would quickly discover that his own ridicule could be fully applied to his affirmative product, whatever it might be.

2 Id. at 484. 
that the "impact" on the plaintiff is "irrelevant" to standing was limited to cases challenging public disbursements, this Court decided that if that view was valid for such cases, it should be valid for other problems of standing. Said the Court: "The test of standing is citizenship, not the impact on the plaintiff. This plaintiff is not a citizen, and the impact of the governmental action on him is irrelevant. Therefore, he lacks standing to challenge the order that he be executed."

The unanimity of commentators and editorial writers has convinced us that we should reexamine our position, and we have done so. We now see that the "impact" of execution is not "irrelevant" to the standing of one who is about to be executed. Indeed, the impact seems to be the key factor.

Accordingly, we overrule all three Chiang decisions. A citizen who has nothing at stake lacks standing. A citizen or noncitizen who has something at stake has standing.

Judgment affirmed. 